\title{
A 1200 year record of accumulation from northern Greenland
}

\author{
Arne Friedmann, ${ }^{*}$ John C. Moore, ${ }^{\dagger}$ \\ Arctic Centre, University of Lapland, P.O. Box 122, 96101 Rovaniemi, Finland \\ Thorsteinn Thorsteinsson, Josef Kipfstuhl, \\ Alfred-Wegener-Institut für Polar- und Meeresforschung, Columbusstrasse, 27515 Bremerhaven, Germany \\ Hubertus Fischer \\ Institut für Umweltphysik, Im Neuenheimer Feld 366, 69122 Heidelberg, Germany
}

\begin{abstract}
We present the first detailed study of regional and secular changes in accumulation rate from northern Greenland. Four $100-150 \mathrm{~m}$ ice cores from this previously little investigated region have been dielectrically profiled and a good chronology for all four ice cores established by modelling the density profiles and identifying volcanic peaks in the records. This made it possible to calculate the accumulation rates of each core. The current accumulation rates show that there is a large region of low accumulation rate to the northeast of central Greenland with drops in accumulation rate of $25 \% 150 \mathrm{~km}$, and $50 \% 300 \mathrm{~km}$ from Summit.

Relatively large variations in accumulation rate over time are seen in all the cores. We have compared the resulting accumulation-rate record, which should be related to changes in local air temperature over northern Greenland, with Scandinavian tree-ring records and have interpreted the data as showing an early Medieval Warm Epoch, but no pronounced "Little Ice Age" and no unequivocal greenhouse warming effect as yet in northern Greenland.
\end{abstract}

\section{INTRODUGTION}

In summer 1993 four ice cores were drilled on a traverse from Summit to Northice, Greenland. Two $100 \mathrm{~m}$ cores were drilled, at $73^{\circ} 56.4^{\prime} \mathrm{N}, 37^{\circ} 37.8^{\prime} \mathrm{W}$ and $75^{\circ} 15.0^{\prime} \mathrm{N}$, $37^{\circ} 37.4^{\prime} \mathrm{W}$ at elevations of approximately 3080 and $2900 \mathrm{~m}$. Further north, two $150 \mathrm{~m}$ cores were drilled, at $76^{\circ} 37.1^{\prime} \mathrm{N}, 36^{\circ} 24.2^{\prime} \mathrm{W}$ and $78^{\circ} 00.0^{\prime} \mathrm{N}, 36^{\circ} 23.9^{\prime} \mathrm{W}$ at elevations of approximately 2600 and $2340 \mathrm{~m}$ (Fig. 1). The drill sites are located east of the central Greenland ice divide in areas where climatic data are very sparse and limited. The best data on the accumulation rate in the area were obtained in the 1950 s by snow stratigraphy spanning 76 years (Hamilton and others, 1956) at Northice $\left(78^{\circ} 04^{\prime} \mathrm{N}, 38^{\circ} 29^{\prime} \mathrm{W}\right.$, elevation $\left.2345 \mathrm{~m}\right), 40 \mathrm{~km}$ west of the core B19 drilling site. Estimates of accumulation rate in the areas of cores $\mathrm{B} 16, \mathrm{~B} 17$ and $\mathrm{B} 18$ come from

\footnotetext{
*Permanent address: Institut für Physische Geographie, Universität Freiburg, Werderring 4, 79085 Freiburg, Germany.

$\dagger$ To whom correspondence should be addressed.
}

Koch and Wegener (1930) and are based simply on the estimate of a single year's precipitation in the early 20 th century.

All four cores were dielectrically profiled in Greenland. The DEP method, previously described by Moore (1993), was slightly modified for our measurements, allowing whole cores rather than longitudinally cut ones to be profiled. This was accomplished simply by having both electrodes curved to match the core curvature. The electrode width chosen was $2 \mathrm{~cm}$, and measurements were made of the $50 \mathrm{kHz}$ conductance at $2-3 \mathrm{~mm}$ resolution along $0.5 \mathrm{~m}$ sections of core. The $2 \mathrm{~cm}$ width of electrode was expected to provide seasonal resolution for the cores. The DEP profiling was done continuously along the cores, but due to drilling commitments the top 10-15 $\mathrm{m}$ of each core were usually missed. Further analyses (chemistry, stable isotopes, physical properties) are under way on the core and will be discussed in future papers.

\section{DATING}

A preliminary estimate of the accumulation rate can be made from the core depth-density profiles Herron and Langway, 1980). The density profile of the cores was 


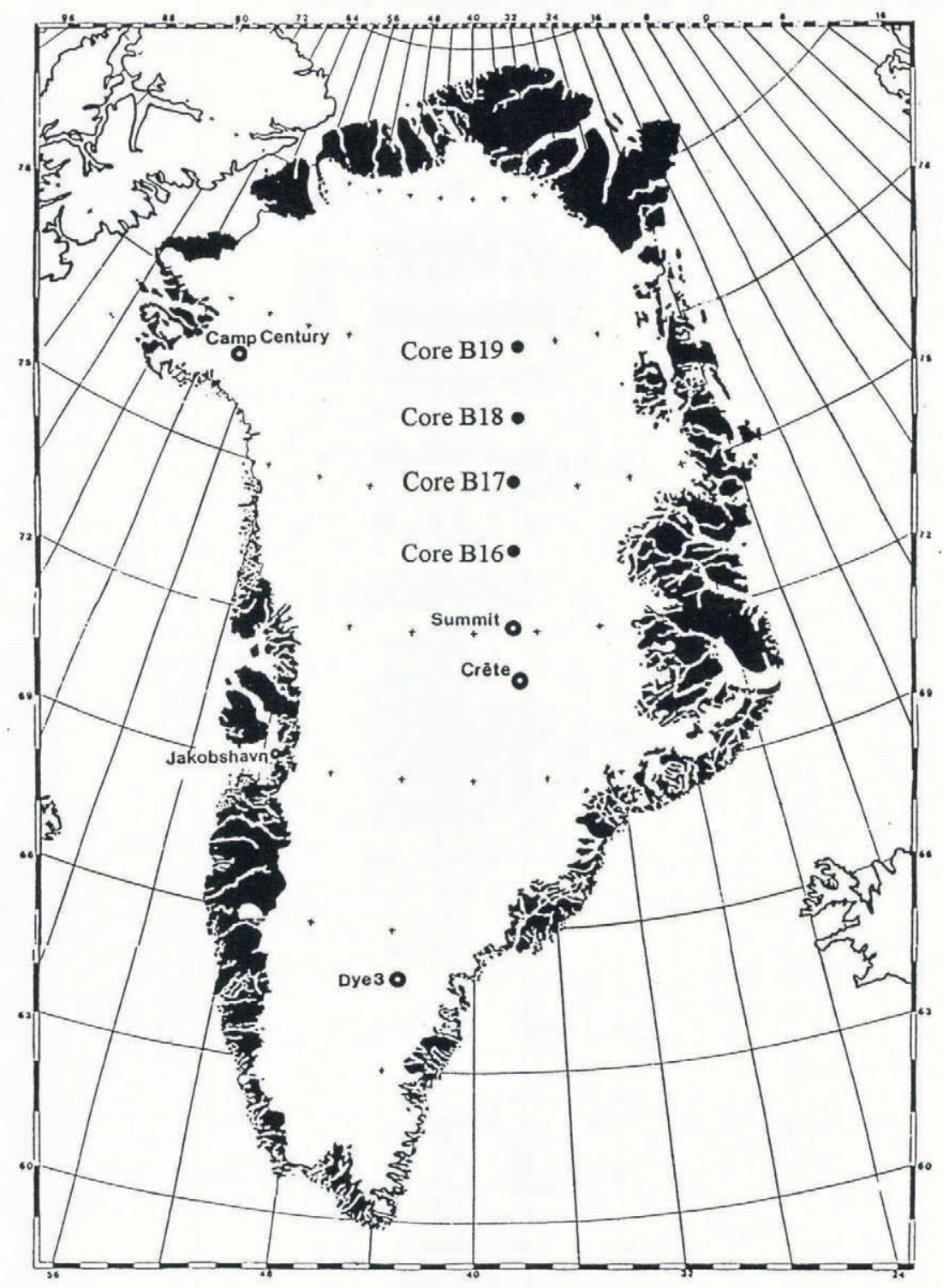

Fig. 1. Greenland map showing the location of Summit and the drill sites of the four cores.

calculated from weight and volume measurements on sections $0.1-0.5 \mathrm{~m}$ in length. The density data were modelled using the empirical firn-densification model of Herron and Langway (1980). The density of solid ice was set at $\rho_{\mathrm{i}}=0.917 \mathrm{Mg} \mathrm{m}^{3}$, and if $\rho$ is the density of firn, the model predicts that plots of $\ln \left[\rho /\left(\rho_{\mathrm{i}}-\rho\right)\right]$ vs depth will consist of straight-line segments. The first segment is for $\rho<0.55 \mathrm{Mg} \mathrm{m}^{-3}$ and the second segment has a shallower slope for $0.55 \mathrm{Mg} \mathrm{m}^{3}<\rho<0.82 \mathrm{Mg} \mathrm{m}$ ${ }^{3}$, corresponding to the first and second stages of densification, respectively. Pore close-off occurs at $\rho=0.82$ to $0.84 \mathrm{Mg} \mathrm{m}^{-3}$, below which densification occurs more slowly. The slope of the second segment gives the accumulation rate. The best fit of the model to the data was found with the second stage of densification starting at about $16 \mathrm{~m}$ depth, giving an accumulation rate of 0.15 to 0.1 m year $^{-1}$, depending on the core. A depth-age relationship was then calculated to establish an approximate chronology for the core.

A more detailed and accurate chronology can be obtained from the depths of dated stratigraphic horizons. One commonly used technique is to identify the snow layers containing the acid deposition from historically known volcanic eruptions (Hammer, 1980; Hammer and others, 1980; Moore and others, 1991). The DEP conductivity largely depends on the acid concentration in the ice (Moore and others, 1992). Numerous sharp peaks in the DEP profile, representing volcanic eruptions, were identified in all the cores. At depths of $49.3 \mathrm{~m}$ (core B16), $43.2 \mathrm{~m}$ (B17), $40.2 \mathrm{~m}$ (B18) and $37.3 \mathrm{~m}$ (B19), large peaks were seen, which were identified as the signal from the eruption of Laki (Iceland) in 1783 (Fig. 2a) based on the calculated chronology from the densification profile and the known characteristics of the signal from many other ice cores in Greenland (e.g. Clausen and Hammer, 1988). We are very confident in our identification of the peak because it was seen in all four cores, was the largest signal in the top $100 \mathrm{~m}$ (Fig. 3) and was within $5 \mathrm{~m}$ of the depth expected from the densification rate; furthermore, cycles in the DEP conductivity were often observed which correspond closely with the predicted annual layer thickness. Average accumulation rates for the cores from the surface to the Laki horizon were calculated, and the whole length of the ice cores was dated using these accumulation rates.

Important volcanic eruptions since $1500 \mathrm{AD}$ have been 

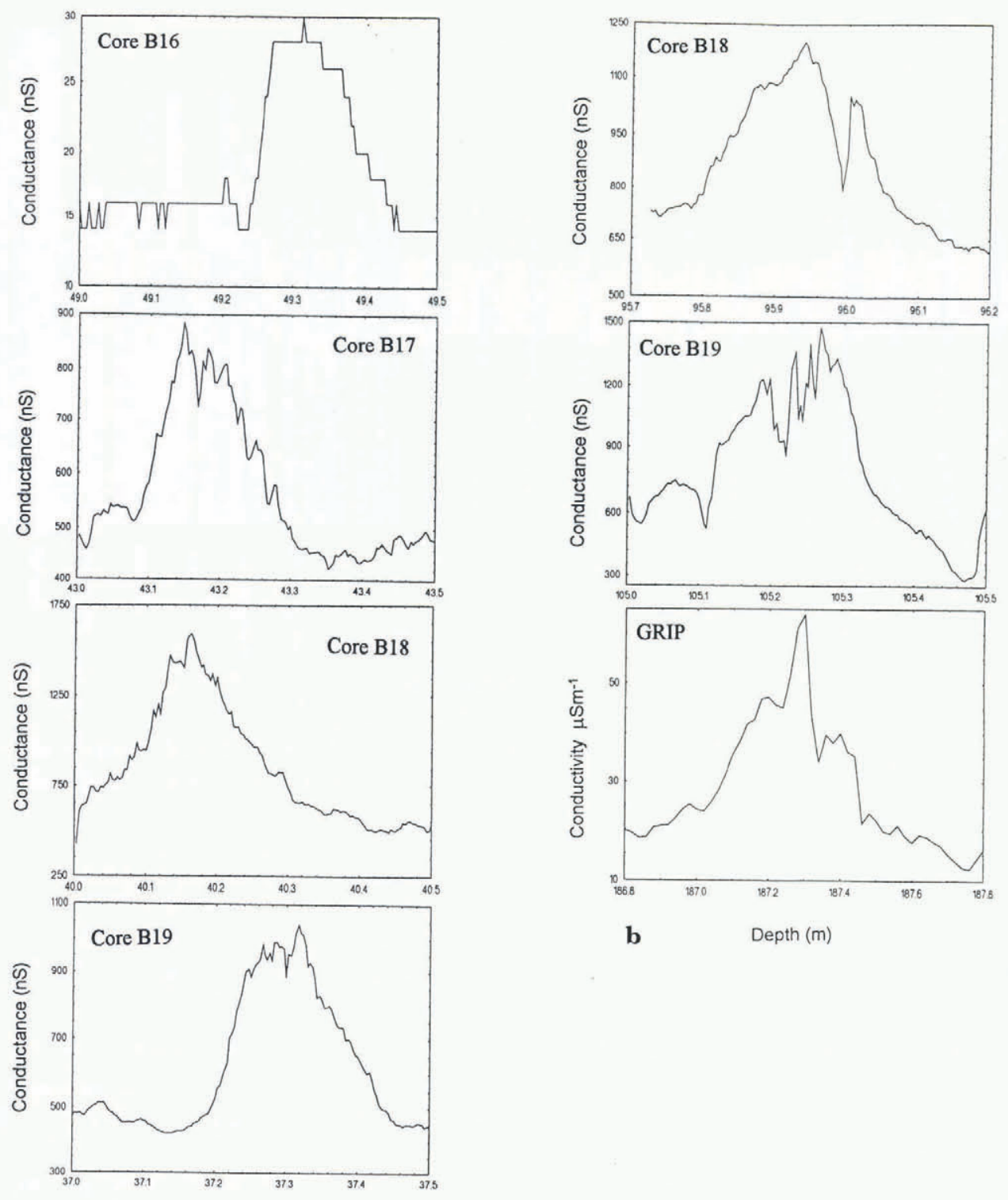

b

Depth $(m)$

a

Depth (m)

Fig. 2.a. Detailed DEP conductance profiles showing the 1783 eruption of Laki (Iceland) in all four ice cores. b. 1259 eruption of an unknown volcano from cores B18 and B19 logether with the conductivity $\left(a t-15^{\circ}\right.$ C) profile for the GRIP core. Note the $1 \mathrm{~m}$ length of the GRIP plot, to compensate for the roughly double accumulation rate at GRIP relative to drill sites B18 and B19.

listed in the dust-veil index (DVI) of Lamb (1970) and the volcanic explosivity index (VEI) of Newhall and Self (1982). Volcanic-acid signals have been dated in ice cores from central Greenland: Crête Hammer and others, 1980), the combined GRIP and Eurocore records Clausen and others, in press) and other Greenland cores (Hammer, 1984; Clausen and Hammer, 1988). Using the preliminary chronology of the cores, 20 peaks were found in the DEP profile that could be identified with known or previously dated volcanic eruptions (Table 1). At depths of $28 \mathrm{~m}$ (core B16), $25 \mathrm{~m} \mathrm{(B17),}$ $23.4 \mathrm{~m} \mathrm{(B18)}$ and $24.95 \mathrm{~m} \mathrm{(B19),} \mathrm{a} \mathrm{melt} \mathrm{layer} \mathrm{was} \mathrm{found.}$ It has been identified previously in many central Greenland ice cores and dated to the year 1889 by Clausen and others (1988). All four cores contain signals going back to about 1500 ; only the $150 \mathrm{~m}$ long cores B 18 and B19 show peaks from eruptions earlier than 1479 (Mount St. Helens). Figure 3 shows the DEP peak amplitudes for the signals in the four cores after correction of the DEP conductivity for the effects of density (Moore and others, 1991). Two fairly prominent peaks were seen in addition to those observed in other Greenland cores: these are peaks 11 and 18, which we dated from the Laki horizon and the densification model at about 1290 and 990, respectively. In contrast with ice cores from Summit Clausen and others, in press) no obvious signal was seen around the year 1810 in any of the four cores; but Table 1 and Figure 3 show that a volcanic peak often shows up weakly or not at all in a core, presumably as a result of differences in acid fall-out on both scales typical of surface sastrugi and longer distances characterizing individual precipitation events. 


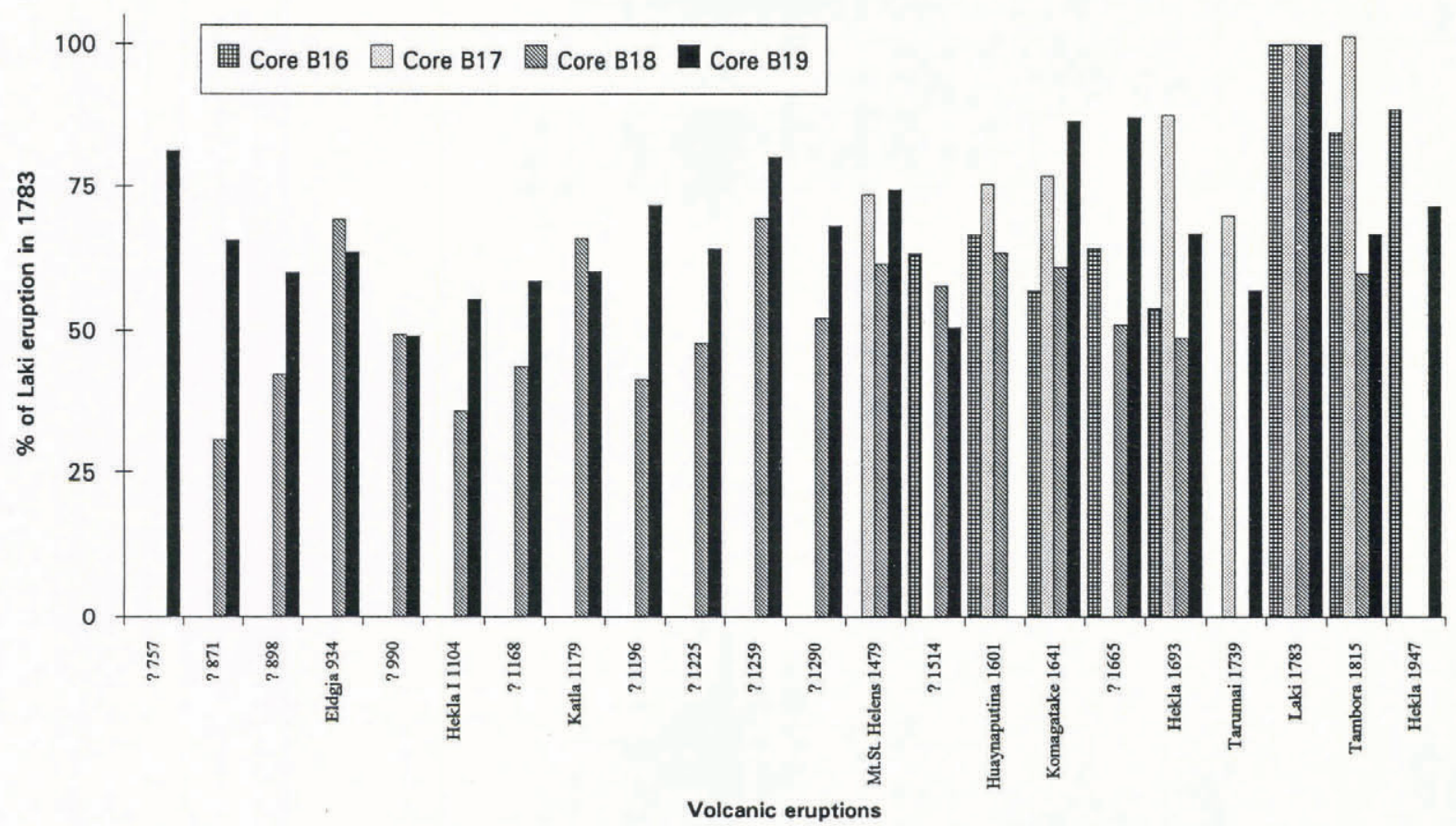

Fig. 3. Relative peak height of DEP signals in the four cores corrected for core density using the Looyenga model of dielectric mixtures (Moore and others, 1991, equation 3). Peak heights are relative to the Laki eruption of 1783, which is set to $100 \%$.

Table 1. List of identified reference horizons and calculated accumulation rates in the four cores

\begin{tabular}{|c|c|c|c|c|c|c|c|c|c|c|}
\hline \multirow{3}{*}{$\begin{array}{c}\text { Volcanic } \\
\text { peak } \\
\text { No. }\end{array}$} & \multirow[t]{3}{*}{ Year } & \multirow[t]{3}{*}{ Horizon } & \multicolumn{4}{|c|}{ Depth } & \multicolumn{4}{|c|}{ Accumulation rate } \\
\hline & & & B16 & $B 17$ & B18 & B19 & $B 16$ & B17 & B18 & $B 19$ \\
\hline & & & $\mathrm{m}$ & $\mathrm{m}$ & $\mathrm{m}$ & $\mathrm{m}$ & $m_{\text {year }}^{-1}$ & $m_{\text {year }}{ }^{-1}$ & $m_{\text {year }}^{-1}$ & $\mathrm{~m}_{\text {year }}{ }^{-1}$ \\
\hline \multirow{3}{*}{1} & 1993 & & 0 & 0 & 0 & 0 & 0.126 & 0.113 & 0.104 & 0.110 \\
\hline & 1947 & Hekla & 14 & & & 12.6 & 0.139 & - & - & 0.114 \\
\hline & 1889 & Melt layer & 28 & 25 & 23.4 & 24.95 & 0.134 & 0.110 & 0.101 & 0.069 \\
\hline 2 & 1815 & Tambora & 42.8 & 37.8 & 35.4 & 32.6 & 0.148 & 0.116 & 0.101 & 0.099 \\
\hline 3 & 1783 & Laki & 49.3 & 43.2 & 40.2 & 37.3 & 0.140 & 0.094 & 0.098 & 0.090 \\
\hline 4 & 1739 & Tarumai & 57.4 & 49 & - & 43 & 0.118 & 0.120 & - & 0.095 \\
\hline 5 & 1693 & Hekla & 64.3 & 56.4 & 52.5 & 49 & 0.172 & 0.115 & 0.097 & 0.088 \\
\hline 6 & 1665 & ? & 70.3 & - & 56.1 & 52.3 & 0.136 & - & 0.109 & 0.101 \\
\hline 7 & 1641 & Komagatake & 74.3 & 64.1 & 59.5 & 55.5 & 0.139 & 0.152 & 0.098 & 0.098 \\
\hline 8 & 1601 & Huaynaputina & 81.05 & 71.77 & 64.5 & - & 0.147 & 0.115 & 0.092 & - \\
\hline 9 & 1514 & $?$ & 96.3 & - & 74.5 & 71.1 & - & - & 0.122 & 0.103 \\
\hline 10 & 1479 & Mount St. Helens & - & 88.6 & 79.7 & 75.5 & & & 0.102 & 0.077 \\
\hline 11 & 1290 & $?$ & & - & 102.6 & 93 & & & 0.075 & 0.082 \\
\hline 12 & 1259 & ? & & & 105.3 & 96 & & & 0.079 & 0.072 \\
\hline 13 & 1225 & ? & & & 108.4 & 98.9 & & & 0.107 & 0.094 \\
\hline 14 & 1196 & $?$ & & & 112 & 102.1 & & & 0.092 & 0.105 \\
\hline 15 & 1179 & Katla & & & 113.8 & 104.1 & & & 0.095 & 0.094 \\
\hline 16 & 1168 & $?$ & & & 115 & 105.4 & & & 0.085 & 0.087 \\
\hline 17 & 1104 & Hekla 1 & & & 121.3 & 111.9 & & & 0.100 & 0.118 \\
\hline 18 & 990 & $?$ & & & 134.4 & 127.5 & & & 0.119 & 0.111 \\
\hline 19 & 934 & Eldgja & & & 142 & 134.7 & & & 0.108 & 0.075 \\
\hline 20 & 898 & ? & & & 146.4 & 137.8 & & & 0.104 & 0.083 \\
\hline 21 & 871 & $?$ & & & 149.2 & 140 & & & & 0.069 \\
\hline 22 & 757 & $?$ & & & - & 148.7 & & & & \\
\hline
\end{tabular}




\section{RESULTS AND DISGUSSION}

\section{Spatial variation of accumulation}

Ice thickness in the region of the cores varies between 2900 and $2400 \mathrm{~m}$ (Radok and others, 1982). Since the cores were drilled either at the ice divide (core B16) or in areas with low surface gradients where horizontal velocities are about 10 mear $^{-1}$ (Radok and others, 1982), only minimal ice flow occurs. No correction for an upstream accumulation gradient was needed, since the area the snow originated from is only a few kilometres from the drill sites. The ice cores penetrated about $5 \%$ of the ice thickness, and to good approximation differential thinning of layers with depth can be neglected. Therefore, a good estimated average accumulation rate for the period between two dated volcanic-reference horizons can be calculated from the (density-corrected) core length separating them (Table 1).

Core B16 showed a mean accumulation rate of $0.14 \pm 0.014 \mathrm{myear}^{-1}$, core $\mathrm{B} 17$ a rate of $0.117 \pm$ $0.016 \mathrm{~m}_{\text {year }}^{-1}$, core $\mathrm{B} 18$ a rate of $0.099 \pm 0.012 \mathrm{~m}_{\text {year }}^{-1}$ and core $\mathrm{B} 19$ a rate of $0.0925 \pm 0.0145$ m year $^{-1}$. As expected from maps of accumulation rate of the area compiled from earlier sparse measurements Ohmura and Rech, 1991), our data indicate a significant decrease in accumulation from south to north. They also suggest a much larger area of low accumulation rate in the region to the northeast of Summit (Fig. 4) than given by Ohmura and Reeh (1991). The data used in this region by Ohmura and Reeh (1991) were from the rather limited measurements of Koch and Wegener (1930), who estimated precipitation rates at points along a traverse across northern Greenland from the depth of the surface softsnow layer. Their working hypothesis was that this softsnow layer represented snowfall since the previous summer, but they acknowledged that this assumption, and consequently their precipitation-rate figures, might be incorrect. The best data in the whole region come from the pit study made by H. Lister $40 \mathrm{~km}$ west of drill site B19, of 76 years of accumulation spanning 1877-1953 at Northice Hamilton and others, 1956). This found values between 0.05 and $0.14 \mathrm{~m}_{\text {year }}{ }^{-1}$ which are in good agreement with our data for core B19. We therefore propose a modified accumulation map for northeast Greenland (Fig. 4). As described by Ohmura and Reeh (1991), northeast Greenland precipitation patterns are dominated by Atlantic influences. Storm tracks come from the south or southwest of Greenland and Iceland governed by the Icelandic low and are mostly rained out along the southwest coast or the Summit area before reaching the northeast. The remote setting of northeast Greenland, which is blocked off to the west by the central Greenland ice divide and to the south by the Summit area from moisture sources and major storm-track lines, causes a large area to have a very low accumulation rate. The area descending northwards from the Summit plateau shows an especially rapidly declining accumulation rate. In contrast to the Summit area whose moisture sources are the North Atlantic mid-latitudes (Johnsen and others, 1989; Fisher, 1990), it is likely that the more northerly sites, especially cores B 18 and B 19 , receive more moisture from local sources in the Greenland Sea, Arctic Ocean and Canadian wetlands.

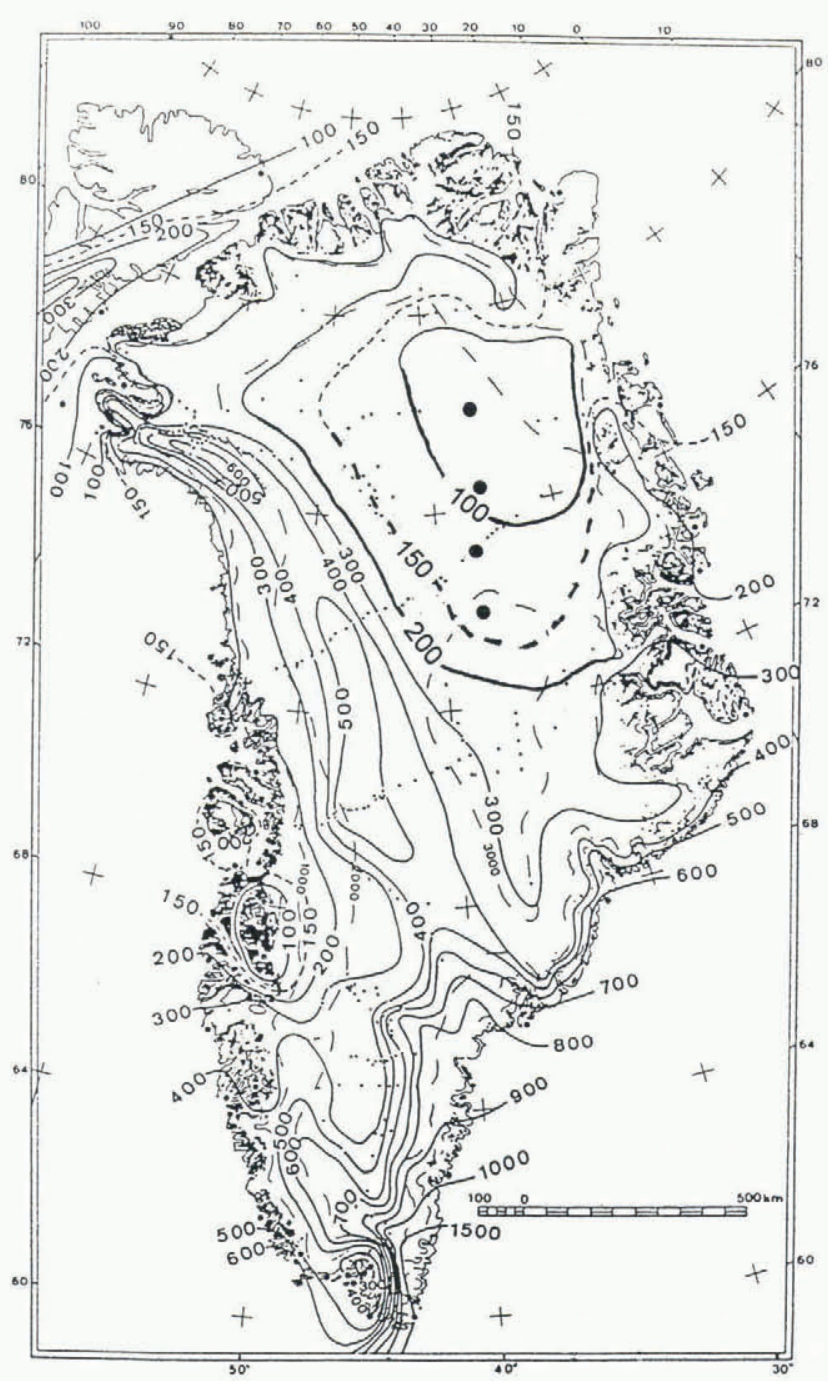

Fig. 4. Revised accumulation map for Greenland, showing significant differences from the Ohmura and Reeh (1991) map in the north and northeast of Greenland. Light accumulation-rate contours from Ohmura and Reeh (1991, fig. 6) and heavy lines are modifications based on data presented here.

\section{Temporal variations}

Precipitation and accumulation rates are related to the water-vapour content in the air above the surface inversion layer and thus to its temperature (e.g. Robin, 1977). Clausen and others (1988) found a good correlation between stable oxygen-isotope ratios and accumulation rates in ice cores from central Greenland, supporting a link between accumulation rate and local air temperature. We present the accumulation-rate records in Figures 5 and 6 . The average accumulation rates are calculated at uneven intervals because of the random spacing of our volcanic horizons in time through the core records. Therefore, we are not able to show the actual onset of, for example, a drier trend; all we can say is that a change occurred at some time between our time markers, which are on average separated by 50 years. This has the general effect of reducing variations in accumulation rate.

20th-century accumulation appears little different from the average for the cores, except for core B19 which records 


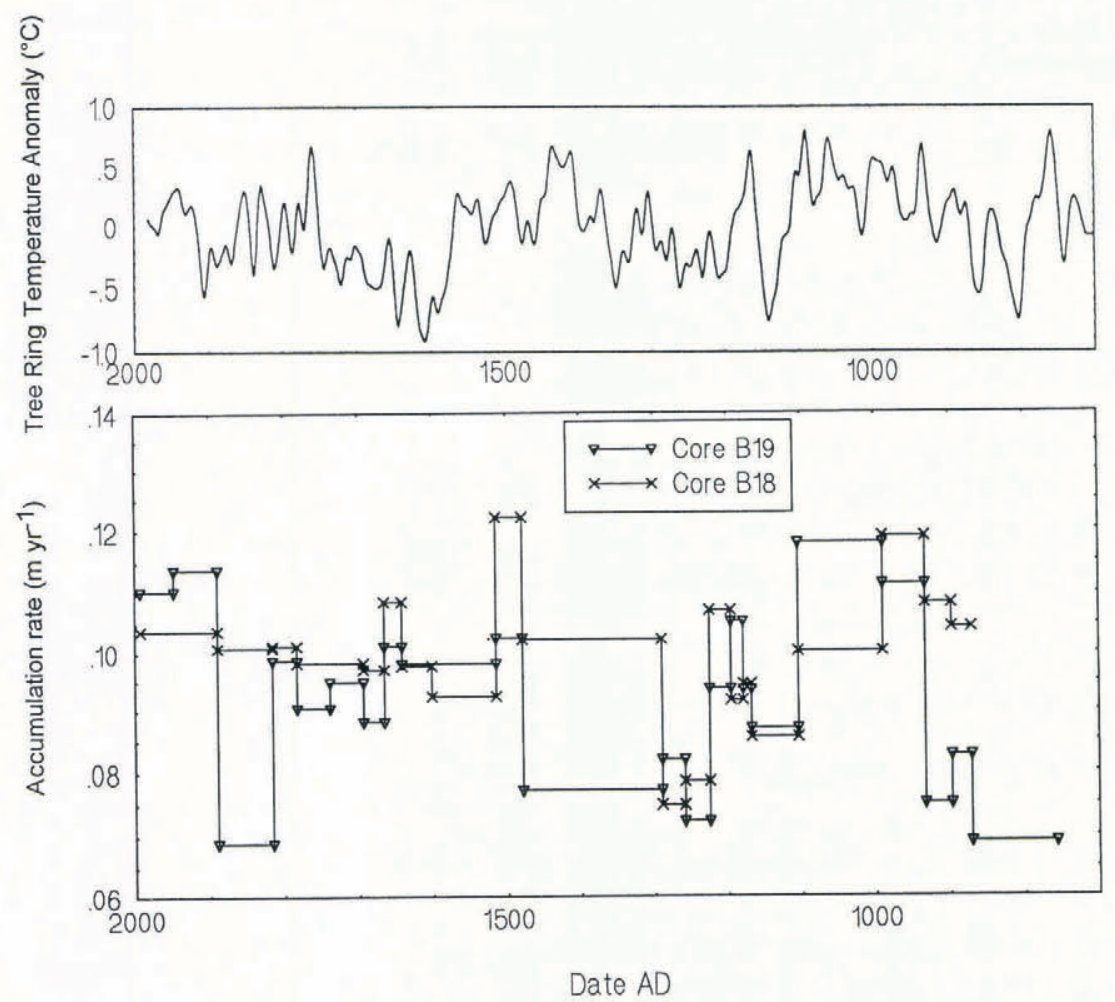

Fig. 5. Accumulation-rate records for cores B18 and B19, 700-1993 AD. The Fennoscandinavian tree-ring record of Briffa and others (1990) is plotled for comparison.

a very dry period 1815-90 followed by much higher accumulation rates up to the present. Hamilton and others' (1956) accumulation record from Northice between 1877 and 1953 shows a minimum in the 1940 s with half the accumulation rate of the 1880 s or 1950s. Our much longerterm averages cannot reveal this detail between our 1889 and 1947 marker horizons, but the range of variability appears to be similar to that in Figure 5 .
We have sought to correlate our record with proxy climate data from other high-latitude areas. One such proxy is tree-ring growth, which is related to summer temperatures. The comparison of our data with tree-ring records from northern Fennoscandia (Briffa and others, 1990) (Fig. 5) shows some similarities but also differences. From 900 to 1100 we find a pronounced wet period, represented by the highest accumulation rates in the

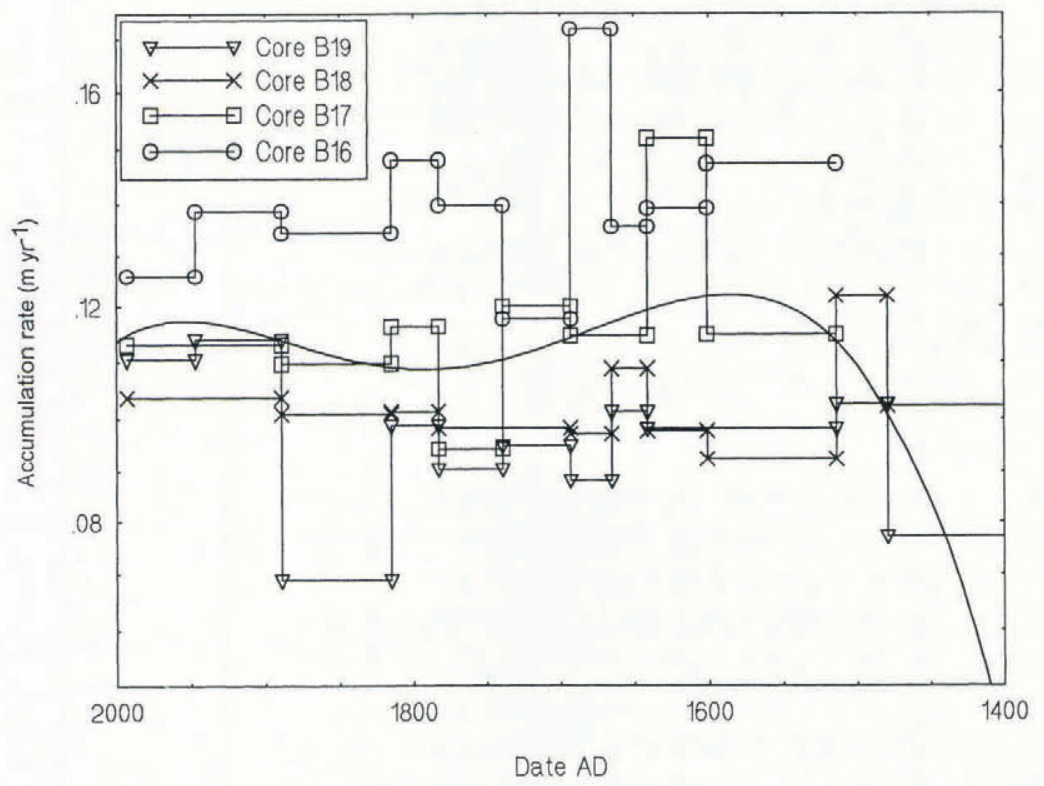

Fig. 6. Accumulation rate records of cores B16, B17, B18 and B19 for the years 1400-1993 AD. A fifth-order polynomial fit to all four records over this period is superimposed on the record; the earlier part of this curve showing a steep decline is unrealistically affected by the low values in cores B18 and B19 prior to $1500 \mathrm{AD}$. 
whole record for cores $\mathrm{B} 18$ and $\mathrm{B} 19$, somewhat similar to the tree-ring record, which might be comparable to the Medieval Warm Epoch in central Europe. This period of prolonged wet and warmth started and ended earlier and was shorter in northern Greenland than in central Europe, where it lasted from about 1000 to 1300.

The "Little Ice Age" does not show up clearly in our records, whereas it might have been expected to produce dry conditions, and was also absent from the Fennoscandian tree-ring data. There are minima, periods of low accumulation in the ice cores, but no uniform dry period or general trend is detectable during the period 1200 1900 , which is referred to as the maximum time span of the "Little Ice Age" in central Europe. No simple signature of global warming is to be found in our ice cores, which would manifest itself as an increase in accumulation rate over the last 100 years or so, except in core B19, where a dramatic increase occurs.

\section{CONGLUSION}

The large region of low accumulation to the northeast of Summit in Greenland investigated here presents an apparently attractive site for drilling to bedrock in future. The low accumulation rates mean that ice from the last Interglacial (Eemian) should be nearer the surface and consequently less likely to have suffered the flow disturbances that may have occurred at Summit (Taylor and others, 1993). However, the region is in a different climatic regime from central Greenland and appears to receive moisture from various, more or less localized, source areas. The large variation in accumulation rates seen over the last 1200 years, during what at Summit appears to be a remarkably stable period of climatic history, suggests that interpretation of regional and global climate from an ice core in the region will not be straightforward.

\section{ACKNOWLEDGEMENTS}

We thank the British Antarctic Survey for the loan of the DEP equipment which enabled core interpretation to be done in the field. The hard work and commitment of the drillers in recovering the ice cores is appreciated. This was a GRIP associated project and we thank the GRIP Operations Centre for logistical support.

\section{REFERENCES}

Briffa, K. R. and 6 others. 1990. A 1,400-year tree-ring record of summer temperatures in Fennoscandia. Nature, 346 6283), 434439.

Clausen, H.B. and C. U. Hammer, 1988. The Laki and Tambora eruptions as revealed in Greenland ice cores from 11 locations. Amn. Glaciol., 10. $16-22$

Clausen. H. B., N.S. Gundestrup, S.J. Johnsen, R. Bindschadler and J. Zwally. 1988. Glaciological investigations in the Grête area, central Greenland: a search for a new deep-drilling site. Ann. Glaciol., 10, 10-15.

Clausen, H. B. and 6 others. In press. 1250 years of global volcanism as revealed by central Greenland ice cores. In Ice core studies of global biogeochemical cycles, NATO Advanced Research Workshop. Annecy. France, March 1993.

Fisher, D. A. 1990. A zonally-averaged stable-isotope model coupled to a regional variable-elevation stable-isotope model. Ann. Glaciol., 14, 65-71.

Hamilton, R. A. and 6 others. 1956. British North Greenland Expedition 1952 4: scientific results. Geogr. J., 122, Part 2, 203240.

Hammer, C. U. 1980. Acidity of polar ice cores in relation to absolute dating, past volcanism, and radio-echoes. J. Glaciol., 25 93), 359372.

Hammer, C. U. 1984. Traces of Icelandic eruptions in the Greenland ice sheet. Jökull, 34, 51-65.

Hammer, C. U., H. B. Clausen and W. Dansgaard. 1980. Greenland ice sheet evidence of post-glacial volcanism and its climatic impact. Valure, 288 5788), $230-235$.

Herron, M. M. and C. C. Langway, Jr. 1980. Firn densification: an empirical model. J. Glaciol., 25 93), 373-385.

Johnsen, S.J., W. Dansgaard and J. W. C. White. 1989. The origin of Arctic precipitation under present and glacial conditions. Tellus, 41B 4), 452-468.

Koch, J.P. and A. Wegener. 1930. Wissenschaftliche Ergebnisse der dänischen Expedition nach Dronning Louises-Land und quer über das Inlandeis von Nordgrönland 1912 13. Medd. Grönl., 75.

Lamb, H. H. 1970. Volcanic dust in the atmosphere; with a chronology and assessment of its meteorological significance. Philos. Trans. R. Soc. London, Ser. A, $\mathbf{2 6 6} 1178$, 425-533.

Moore, J.C. 1993. High resolution dielectric profiling of ice cores. J. Glaciol., $39(132), 245248$.

Moore, J. C., H. Narita and N. Maeno. 1991. A continuous 770-year record of volcanic activity from East Antarctica. 3. Geophys. Res., 96 D9), 17,353 17,359.

Moore, J. C., E. W. Wolff, H. B. Clausen and C. U. Hammer. 1992. The chemical basis for the electrical stratigraphy of ice. 7. Geophys. Res.. 97 B2 . 1887-1896.

Newhall, C. G. and S. Self. 1982. The volcanic explosivity index (VEI): an estimate of explosive magnitude for historical volcanism. J. Geophys, Res., 87 C:2 , 1231-1238.

Ohmura, A. and N. Reeh. 1991. New precipitation and accumulation maps for Greenland. f. Glaciol., 37 125), 140-148.

Radok. U., R. G. Barry, D. Jenssen, R. A. Keen, G. N. Kiladis and B. McInnes. 1982. Climatic and physical characteristics of the Greenland ice steel. Boulder, CO, University of Colorado. Cooperative Institute for Research in Environmental Sciences.

Robin, G. de Q. 1977. Ice cores and climate change. Philos. Trans. R. Soc. London, Ser. B, 280 972), 143-168.

Taylor, K. C. and 9 others. 1993. Electrical conductivity measurements from the GISP2 and GRIP Greenland ice cores. Nalure, 366 6455 , 549-552. 